\title{
EFFECT OF FOLIAR APPLICATION OF MICRONUTRIENTS, MAGNESIUM AND WRAPPING FILMS ON YIELD, QUALITY AND STORABILITY OF GREEN BEAN PODS
}

Shehata, S.A.*, Said, Z. A., Manal M. Attia ** and Rageh, M.A. **

* Faculty of Agriculture, Cairo University, Giza, Egypt

** Postharvest and Handling of Vegetable Crops Department. Horticulture Research Institute. Agriculture Research Center, Giza, Egypt.

\section{ABSTRACT}

This study was carried out under plastic house conditions during autumn seasons of 2012/2013 and 2013/2014 at the Agricultural Experiment and Researches Station, Faculty of Agriculture, Cairo University on Morelado cv. to study the effect of foliar spraying by Iron at $100 \mathrm{ppm}+$ Manganese at $100 \mathrm{ppm}+$ Zinc at $50 \mathrm{ppm}$ or Magnesium at $0.5 \%$ concentrations on productivity, quality and storability of snap bean during storage at $6{ }^{\circ} \mathrm{C}$ and $95 \% \mathrm{RH}$. Results showed that green bean plants sprayed with Iron at $100 \mathrm{ppm}+$ Manganese at $100 \mathrm{ppm}+$ Zinc at $50 \mathrm{ppm}$ were, significantly, the highest in all vegetative growth parameters compared with other treatments. Foliar application with Iron at $100 \mathrm{ppm}+$ Manganese at $100 \mathrm{ppm}+$ Zinc at $50 \mathrm{ppm}$ or magnesium at $0.5 \%$ increase leaves chlorophyll content without significant differences between them. Foliar application with Iron at $100 \mathrm{ppm}+$ Manganese at $100 \mathrm{ppm}+$ Zinc at $50 \mathrm{ppm}$ or magnesium at $0.5 \%$, significantly increased the total yield and its components with significant differences between them and also improved the pods quality. Results showed that with prolonging the storage period at $6{ }^{\circ} \mathrm{C}$ and $90-95 \% \mathrm{RH}$, weight loss $\%$ of pods increased, but general appearance, total chlorophyll and ascorbic acid content were reduced. Green bean pods from plants sprayed with Iron at $100 \mathrm{ppm}+$ Manganese at $100 \mathrm{ppm}+$ Zinc at $50 \mathrm{ppm}$ gave less weight loss \% and high values of chlorophyll and ascorbic acid contents, also maintained good appearance for 16 days storage at $6{ }^{\circ} \mathrm{C}+95 \% \mathrm{RH}$.

Concerning the effect of packaging material, snap bean pods packed in polypropylene or stretch reduced the weight loss percentage as compared with unpacked pods during storage in the two seasons, however, polypropylene film was the most effective treatment in reducing the loss in pods weight compared with those packed in stretch film. Snap bean stored in polypropylene film was perceived to have the highest intensities of freshness, greenness and crispness, while unpacked control was perceived to have low intensities of these attributes. The highest total chlorophyll content was obtained from pods packaged in polypropylene film followed by those packed in stretch film with significant differences between them. However, the lowest ones was obtained from unpacked pods during

Fayoum J. Agric. Res. \& Dev., Vol. 29, No.1, January, 2015 
Shehata, S.A. et al.

storage. Snap bean pods packed in polypropylene or stretch film were significantly higher in ascorbic acid with no significant differences between them than unpacked pods during storage.

\section{INTRODUCTION}

Green bean (Phaseolus vulgaris L.) is one of the most important leguminous crops in Egypt for exportation and local consumption. Macronutrients are just as important in plant nutrition as micronutrients. Plants grown on macro or micronutrients deficit soil or soil with problems in supplying plants can exhibit similar reduction in plant growth and yield. Attempts have bean made to assess the importance of micronutrients (Mn, Fe and $\mathrm{Zn}$ ) and macronutrients such as $\mathrm{Mg}$ for snap bean plants to enhance nitrogen fixation and regulate soil $\mathrm{pH}$ to induce microorganisms activation in rizosphere around plant root to attain maximum photosynthesis capacity, water and minerals uptake and dry matter accumulation which greatly affect snap bean plant growth and productivity.

Magnesium is the central atom of the chlorophyll molecule and play an important nonspecific role in the process of phosphate transfer. It also acts as an activator certain enzymic reactions (Delvin and Witham, 1986). The $\mathrm{Mg}$ application enhanced snap bean growth, yield and quality as reported by WangHong and Bao,(1999), Mohammed et al.(2009), Olivira et al.(2000), Swiereczewska and Sztuder (2001) and Ibrahim et al. (2010).

Zinc is a component of variety of enzymes such as dehydrogenase, proteinase, peptidase and phosphoryllases(metabolism of carbohydrate, protein and phosphate). Zinc is known to simulate plant resistance to dry and hot weather and also to bacterial and fungal diseases(Kabata and Pendias,1992, Srivasta and Gupta,1996). Spraying snap bean with $\mathrm{Zn}$ at $50 \mathrm{ppm}$ increased pod yield and pod length (El-Sayed, 1991a).

Iron is a factor for approximately 140 enzymes that catalyze unique biochemical reactions (Brittenhan,1994). Iron is critical for chlorophyll formation and photosynthesis and is important in the enzyme systems and respiration of plants (Havlin et al.,1999).

Spraying plants with Fe gave the highest values of growth characters and green pod yield of pea (Mansour et al., 2012). Increased total chlorophyll as well as yield and its components for broad bean (El- Tantawy and Nawar,2013) increased plant height, pod length and yield per plant for broad bean ( El-Tantawy and Mahmoud, 2013) and increased fresh weight of leaves and number of leaves/ plant as well as plant height in snap bean (ElSayed, 1991a).

Manganese is involved in evolution of $\mathrm{Co}_{2}$ in photosynthesis (Hill reaction). It is a component of several enzyme systems. It has also a function in chloroplast as a part of transport system (Srivasta and Gupta, 1996). Spraying snap bean plants with $\mathrm{Mn}$ increased green pods yield and fresh weight of pod

Fayoum J. Agric. Res. \& Dev., Vol. 29, No.1, January, 2015 
EFFECT OF FOLIAR APPLICATION OF MICRONUTRIENTS

(El- Sayed, 1991a), increased pod length, pod diameter and average pod fresh weight (Mohamed and Kandeel, 1994) and increased number of green pods / plant (El- Bassiony et al., 2010).

Concerning storage period, Mohammed et al. (2009)found that general appearance and dry matter content of snap bean pods decreased with increasing storage period, whereas weight loss, decay and off odor increased with increasing storage period. In addition, spraying snap bean plant with $\mathrm{Mg}$ reduced weight loss, decay and off odor of pos and gave the highest dry matter content as compared with untreated control during cold storage. Also, Soliman (2004) found that foliar spraying of sweet fennel plants with $\mathrm{Mg}$ had positive effects on reducing the incidence of weight loss and decay percentage during storage. Therefore, the objective of this work was to study the effect of foliar application with iron, manganese and zinc and magnesium on productivity and shelf life of snap bean.

\section{MATERIALS \& METHODS}

\section{1) Plastic house experiment}

This experiment was carried out under plastic house conditions during autumn seasons of 2012/2013 and 2013/2014 at the Agricultural Experiment and Research Station, Faculty of Agriculture, Cairo University. Seeds of Morelado cultivar (an ascent cv.) were sown on $16^{\text {th }}$ and $18^{\text {th }}$ September of 2012 and 2013 seasons, respectively. The plastic house was $60 \mathrm{~m}$ long and $9 \mathrm{~m}$ wide $\left(540 \mathrm{~m}^{2}\right)$ and divided into five beds, each was $1 \mathrm{~m}$ wide and $60 \mathrm{~m}$ long. The experiment occupied three beds. Seeds were sown in hills on the two sides of each bed with $50 \mathrm{~cm}$ apart, plants were thinned leaving one plant / hill.

The foliar application treatments were Iron $(\mathrm{Fe})$ at $100 \mathrm{ppm}+$ Manganese $(\mathrm{Mn})$ at $100 \mathrm{ppm}+\mathrm{Zinc}(\mathrm{Zn})$ at $50 \mathrm{ppm}$, and Magnesium $(\mathrm{Mg})$ at $0.5 \%$ as well as the control (sprayed with tab water), and were sprayed three times during the growth period of bean plants at 30,45 and 60 days after sowing. Each experimental unit received 21 of solution for each treatment using spreading agent (super film) in all treatments.

The previous treatments were arranged in a complete randomized block design with three replicates. The area of each plot was $20 \mathrm{~m}^{2}$ with 80 plants. Each replicate considered as one plot. Drip irrigation system and agricultural practices were followed as recommended.

The sources of $\mathrm{Fe}, \mathrm{Mn}, \mathrm{Zn}$ and $\mathrm{Mg}$ were iron sulphate $\left(\mathrm{FeSo}_{4}\right)$, Zinc sulphate $\left(\mathrm{ZnSo}_{4}\right)$, manganese sulphate $\left(\mathrm{Mn} \mathrm{So}_{4}\right)$ and magnesium sulphate $\left(\mathrm{MgSo}_{4}\right)$, respectively. The physical and chemical properties of the loamy soil under study (Table 1) were determined at the soil and water research institute, ARC. 
Shehata, S.A. et al.

Table 1: Physical and chemical analysis of the experimental soil in 2013 and 2014 seasons.

\begin{tabular}{|c|c|c|c|c|c|c|c|c|c|c|}
\hline Season & $\begin{array}{c}\text { Clay } \\
\text { \% }\end{array}$ & Silt \% & $\begin{array}{c}\text { Fin } \\
\text { sand \% }\end{array}$ & $\begin{array}{c}\text { Course } \\
\text { fine \% }\end{array}$ & Texture & PH & EC & \multicolumn{3}{|c|}{$\begin{array}{c}\text { Mineral nutrients (mg / } \\
\text { kg) soil }\end{array}$} \\
\hline $\mathbf{2 0 1 3}$ & 25.4 & 10.0 & 15.8 & 10.2 & Loamy clay & 8.2 & 3.5 & 30.2 & 21.2 & 301.2 \\
\hline $\mathbf{2 0 1 4}$ & 37.2 & 11.0 & 17.9 & 9.8 & Loamy clay & 8.0 & 3.7 & 28.1 & 18.7 & 320.4 \\
\hline & \multicolumn{3}{|c|}{ Cations (Mequvelant / 1 ) } & \multicolumn{5}{|c|}{ Anions (Mequvelant / 1) } \\
\cline { 2 - 9 } & $\mathrm{Mg}^{+2}$ & $\mathrm{Na}^{+2}$ & $\mathrm{Ca}^{+2}$ & $\mathrm{~K}+$ & $\mathrm{HCO}^{-3}$ & \multicolumn{3}{|c|}{$\mathrm{C}^{-1}$} & $\mathrm{So}_{4}{ }^{-2}$ \\
\hline $\mathbf{2 0 1 3}$ & 6.8 & 31.0 & 13.1 & 1.9 & 2.42 & \multicolumn{3}{|c|}{30.1} & 25.2 \\
\hline $\mathbf{2 0 1 4}$ & 7.1 & 33.4 & 15.2 & 2.1 & 2.71 & \multicolumn{3}{|c|}{34.5} & 24.1 \\
\hline
\end{tabular}

Data were recorded as follows:

\section{Vegetative growth}

A representative sample of 6 plants was chosen at random, 60 days after sowing (flowering stage), from each experimental plot for measuring plant growth parameters, i.e. plant height, number of leaves per plant, plant fresh weight and plant dry weight (dried at $65{ }^{\circ} \mathrm{C}$ for 72 hours using the standard methods as illustrated by A.O.A.C (1990). Chlorophyll reading of the sixth mature leaf was measured in SPAD unit, where SPAD $=10 \mathrm{mg}$ chlorophyll $/ \mathrm{g}$ fresh weight using digital chlorophyll meter (Model Minolta Chlorophyll meter SPAD- 502).

\section{Yield and its components:}

At harvest stage ( 75 days from seeds sowing), green pods were collected along the harvesting season (60 days) and the following data were recorded: number of pods / plant, average pod weight and total yield $\mathrm{kg} /$ plot.

\section{Pod quality:}

A random sample of 30 pods from each replicate was taken at harvest and the following characters were measured: pod length, pod thickness, total chlorophyll and ascorbic acid content.

\section{2) Storage experiment}

Snap bean pods which obtained from the previous experiment were harvested in the proper stage of marketing on $22^{\text {th }}$ and $25^{\text {th }}$ of November in the first and second seasons respectively then immediately transported to the Laboratory of Handling of Vegetable Crops Department at Giza. Pods uniform in length, diameter color and free from blemishes were selected for storage experiment and placed in polystyrene trays and each had $200 \mathrm{~g}$ of snap bean pods and served represented as one replicate and over wrapped with polypropylene $(40 \mu \mathrm{m}$ thickness) or stretch film $0.9 \mu \mathrm{m}$ beside unwrapped as a control. Twelve replicates were prepared for each packaging material and the control and then stored at $6{ }^{\circ} \mathrm{C}$ and $95 \% \mathrm{RH}$ for 16 days. Samples were taken randomly in 3 replicate and the samples were examined immediately after harvest and at four days intervals in a complete randomized design with three replications, for the following properties.

Fayoum J. Agric. Res. \& Dev., Vol. 29, No.1, January, 2015 
1. Weight loss percentage was estimated according to the following equation:

Weight loss $\%=$ initial weight of fruits-weight of fruits at sampling date /initial weight of fruits $* 100$

2. General appearance was determined according to the following score : $9=$ excellent , $7=$ good, $5=$ fair, $3=$ poor, $1=$ unusable . This scale depends on morphological defects such as shriveling (wilting), color change of pod surface for physiological defects.

3. Total chlorophyll: total chlorophyll was determined according to

A.O.A.C.(1990).

4. Ascorbic acid: was determined according to A.O.A.C.(1990).

All data were subjected to statistical analysis according to the method described by Snedcor and Cochran (1980).

\section{RESULTS AND DISCUSSION}

\section{Vegetative growth}

Data in Table 2 showed that spraying snap bean plant with either $\mathrm{Fe}$ at $100 \mathrm{ppm}+\mathrm{Mn}$ at $100 \mathrm{ppm}$ and $\mathrm{Zn}$ at $50 \mathrm{ppm}$ or $\mathrm{Mg}$ at $0.5 \%$ had a beneficial effect on all studied vegetative growth parameters (plant height, number of leaves/plant, plant fresh weight and dry weight of plant compared to the control treatment. In this respect, foliar spray with $\mathrm{Fe}$ at $100 \mathrm{ppm}+\mathrm{Mn}$ at $100 \mathrm{ppm}$ and $\mathrm{Zn}$ at $50 \mathrm{ppm}$ was the most favorable treatment for enhancing growth characters significantly. On the other hand, the lowest values in this respect were recorded in the control.

As for chlorophyll reading (SPAD) in leaves, data in Table2 showed clearly that there were significant differences among foliar spray treatments and the control in total chlorophyll content in snap bean leaves during the two seasons. In this respect, the highest values of chlorophyll readings were recorded as a result of spraying snap bean plants with $\mathrm{Mg}$ at $0.5 \%$ (73.12 and 81.24 SPAD) in the $1^{\text {st }}$ and $2^{\text {nd }}$ seasons, respectively, followed by Fe at $100 \mathrm{ppm}, \mathrm{Mn}$ at 100 ppm and $\mathrm{Zn}$ at $50 \mathrm{ppm}$ with non significant differences between them. On the other hand, the control plants recorded the lowest chlorophyll reading in leaves (68.48 and 75.23 SPAD) in the first and second seasons respectively.

Previous results revealed that vegetative growth parameters and chlorophyll reading of snap bean plants were increased due to the beneficial effects of magnesium on plant growth which may be attributed to its role as the central atom of the chlorophyll molecule and plays an important non specific role in the process of phosphate transfer and the role of $\mathrm{Mg}$ as an activator for certain enzymic reactions (Allison et al., 2001). Many investigators reported that magnesium application caused increases in plant growth (Darwesh and Atress, 2011) on pea and Mohamed et al. (2009) and Ibrahim et al.(2010) on snap bean). 
Shehata, S.A. et al.

Table 2: Effect of foliar spraying with some micro elements on vegetative growth and chlorophyll reading (SPAD) of snap bean plants during 2012 / 2013,2013 / 2014 seasons.

\begin{tabular}{|c|c|c|c|c|c|}
\hline Treatment & $\begin{array}{c}\text { Plant Hight } \\
\text { (cm) }\end{array}$ & $\begin{array}{c}\text { No. of leaves/ } \\
\text { plant }\end{array}$ & $\begin{array}{c}\text { Plant fresh } \\
\text { weight }(\mathbf{g})\end{array}$ & $\begin{array}{c}\text { Plant dry } \\
\text { weight }\end{array}$ & $\begin{array}{c}\text { Chlorophyll } \\
\text { reading (SPAD) }\end{array}$ \\
\hline \multicolumn{6}{|c|}{$\mathbf{2 0 1 2}$ / 2013 } \\
\hline Fe+ Zn+ Mn & 211.52 & 16.34 & 150.26 & 24.65 & 72.50 \\
\hline Mg & 200.45 & 14.83 & 138.41 & 21.72 & 73.12 \\
\hline Cont. & 191.81 & 13.12 & 110.6 & 18.23 & 68.48 \\
\hline LSD at 0.05 level & 3.11 & 1.14 & 5.36 & 1.42 & 0.70 \\
\hline \multicolumn{7}{|c|}{$2013 / 2014$} \\
\hline Fe+ Zn+ Mn & 201.62 & 18.72 & 142.6 & 22.42 & 80.74 \\
\hline Mg & 196.06 & 17.13 & 132.12 & 20.31 & 81.24 \\
\hline Cont. & 189.35 & 14.57 & 117.46 & 17.1 & 75.23 \\
\hline LSD at 0.05 level & 3.41 & 1.23 & 4.72 & 1.31 & 0.56 \\
\hline
\end{tabular}

The promotive effect of iron on growth parameters and chlorophyll readings of snap bean plants, in this study, may be attributed to that iron is necessary for biosynthesis of chlorophyll and cytochrome, besides the function of iron in the metabolism of chloroplast RNA, leading to increase in the biosynthesis and materials (produced and accumulated), consequently, the growth was enhanced (Marchner, 1995). Similar findings with iron foliar application were obtained by Mansour et al. (2012) on pea and El-Tantawy and Nawar (2013) on broad bean. Also higher number of leaves means higher interception of light and higher photosynthesis, photosynthesis is also affected by the presence of Fe and Mn( Kirkby and Rrombeld, 2004). Also, Abd- ElLateaf et al. (1998) revealed that foliar application of either Fe or $\mathrm{Zn}$ gave the tallest plant and increased the pods / plant and the number of branches on mung bean plant.

Concerning the effect of Zinc, El-Tohamy and El-Greadlg (2007) found that foliar application of snap bean plant with zinc significantly improved vegetative growth and gave higher total chlorophyll content in leaves.

Also, Nadergoli et al. (2011) and Teixeira et al. (2004) found that zinc and manganese activate some of enzyme systems and have an important role in cell division and cell lengthening. These two factors lead to the increase of stem height of common bean.

\section{Yield and its components}

Data in Table 3 indicated that there were significant differences due to the tested treatments in both seasons on all studied parameters of yield and its components,i.e., (number of pods/ plant, pod weight and total yield compared to the control treatment. In this connection, foliar spray with (Fe at $100 \mathrm{ppm}+\mathrm{Mn}$ at $100 \mathrm{ppm}$ and $\mathrm{Zn}$ at $50 \mathrm{ppm}$ significantly increased all studied yield and its components parameters followed by magnesium treatment with significant differences between them.

Fayoum J. Agric. Res. \& Dev., Vol. 29, No.1, January, 2015 
The enhancing effect of $\mathrm{Mg}$ on yield and its components, such as sugars, proteins, its regulates the uptake of other plant nutrients, especially phosphorus and it is involved in the results are in harmony with those obtained by Darwesh and Atress (2011), Ibrahim et al.( 2010) and Mohammed et al. (2009) on snap bean. They reported that adding $\mathrm{Mg}$ caused increasing in vegetative growth, pod yield as well as gave best quality of green bean pods. Meanwhile, the enhancing effect of iron on yield and its components may be due to the increasing in photosynthetic pigments. Other investigators recorded a similar trend such as Mansour et al. (2012) on pea and El-Tantawy and Nawar (2013) on broad bean.

For the effect of Zn, Karaman et al.(1999) showed that dry matter production increased with foliar spray of bean plants with $\mathrm{Zn}$.

Applications of micronutrients especially zinc and manganese has a positive effect on formation of stamens and pollens and we can attribute the increase of number of pods per plant to this property of micronutrients. As we know, snap bean is a self pollinated plant, so naturally as the activity of stamens increases, the flowers well fertile well and more number of pods will be produced on the plant (Nadergoli et al., 2011).

Table 3 : Effect of foliar spraying with some micro elements on yield and its components of snap bean plants during $2012-2013,2013$ 2014 seasons.

\begin{tabular}{|c|c|c|c|}
\hline Treatment & No of pods/ plant & Pod weight (gm) & Total yield( kg / m2) \\
\hline \multicolumn{5}{|c|}{$\mathbf{2 0 1 2} / \mathbf{2 0 1 3}$} \\
\hline Fe+ Zn+ Mn & 71.8 & 7.04 & 21.25 \\
\hline $\mathbf{M g}$ & 70.1 & 6.82 & 19.18 \\
\hline Cont. & 66.4 & 6.43 & 16.12 \\
\hline LSD at $\mathbf{0 . 0 5}$ level & 0.34 & 0.11 & 0.98 \\
\hline \multicolumn{5}{|c|}{$\mathbf{2 0 1 3} / \mathbf{2 0 1 4}$} \\
\hline Fe+ Zn+ Mn & 74.4 & 7.27 & 20.53 \\
\hline $\mathbf{M g}$ & 70.2 & 6.90 & 19.40 \\
\hline Cont. & 62.3 & 0.18 & 17.01 \\
\hline LSD at 0.05 level & 1.11 & 0.23 & 0.74 \\
\hline
\end{tabular}

\section{Pod quality}

Data in Table 4 showed that spraying snap bean plant with either Fe at $100 \mathrm{ppm}+\mathrm{Mn}$ at $100 \mathrm{ppm}$ and $\mathrm{Zn}$ at $50 \mathrm{ppm}$ or $\mathrm{Mg}$ at $0.5 \%$ increased their pod quality expressed as average pod length and ascorbic acid and chlorophyll contents with significant differences between them. In this respect, foliar spray with $\mathrm{Fe}$ at $100 \mathrm{ppm}+\mathrm{Mn}$ at 100ppm $+\mathrm{Zn}$ at $50 \mathrm{ppm}$ was the most effective treatment for improving pod quality. These results were true in the two seasons. On the other hand, the lowest record of this character was resulted by untreated control. However, concerning pod thickness, there were no significant differences between treatments and the control in the two seasons.

The improvement of growth of bean plants in response to foliar application of $\mathrm{Fe}, \mathrm{Mn}, \mathrm{Zn}$ and $\mathrm{Mg}$ may result in improving quality of snap bean pods such as length and ascorbic acid and chlorophyll contents of pods (EI-

Fayoum J. Agric. Res. \& Dev., Vol. 29, No.1, January, 2015 
Shehata, S.A. et al.

Tohamy and El- Gready (2007) for zinc Ibrahim et al. (2010) for $\mathrm{Mg}$, (AbdEl-Lateaf et al., 1998) for Fe and Zinc, Mohamoud et al., (2009) for Mn and (Nadergoli et al., 2011) for zinc and manganese.

Table 4: effect of foliar spraying with some micro elements on pod quality during 2012 - 2013, 2013 - 2014 seasons.

\begin{tabular}{|c|c|c|c|c|}
\hline Treatment & $\begin{array}{c}\text { Pod length } \\
(\mathbf{c m})\end{array}$ & $\begin{array}{c}\text { Pod thickness } \\
(\mathbf{c m})\end{array}$ & $\begin{array}{c}\text { Ascorbic acid } \\
(\mathbf{m g} / \mathbf{1 0 0} / \mathbf{g F W})\end{array}$ & $\begin{array}{c}\text { Total } \\
\text { chlorophyll(mg/100g) }\end{array}$ \\
\hline \multicolumn{5}{|c|}{$\mathbf{2 0 1 2 / \mathbf { 2 0 1 3 }}$} \\
\hline Fe+ Zn+ Mn & 13.95 & 0.80 & 23.40 & 110.30 \\
\hline $\mathbf{M g}$ & 13.02 & 0.79 & 22.30 & 107.70 \\
\hline Cont. & 12.70 & 0.78 & 19.10 & 102.40 \\
\hline LSD at $\mathbf{0 . 0 5}$ level & 0.11 & NS & 0.92 & 1.24 \\
\hline \multicolumn{5}{|c|}{$\mathbf{2 0 1 3 / 2 0 1 4}$} \\
\hline Fe+ Zn+ Mn & 13.20 & 0.84 & 27.32 & 121.32 \\
\hline \multicolumn{7}{|c|}{ Mg } & 12.80 & 0.81 & 23.71 & 112.74 \\
\hline Cont. & 11.60 & 0.77 & 21.40 & 100.32 \\
\hline LSD at 0.05 level & 0.13 & NS & 1.07 & 1.72 \\
\hline
\end{tabular}

\section{Storage experiment}

Weight loss percentage

Data in Table 5 showed that weight loss percentage of snap bean pods was increased considerably and consistently with the prolongation of storage period during the two seasons. These results agree with those obtained by Mohammed et al. (2009). The loss in weight may be attributed to respiration and other senescence related metabolic processes during storage (Wills $\boldsymbol{e t}$ al., 1989).

Concerning the effect of foliar spray with micro elements, data showed that snap bean pods obtained from plants treated with (Fe at $100 \mathrm{ppm}+\mathrm{Mn}$ at $100 \mathrm{ppm}$ and $\mathrm{Zn}$ at $50 \mathrm{ppm}$ ) or $\mathrm{Mg}$ at $0.5 \%$ showed reduction in the weight loss percentage during storage in comparison with untreated control. However, snap bean pods obtained from plants treated with $\mathrm{Fe}$ at $100 \mathrm{ppm}+\mathrm{Mn}$ at 100 ppm and $\mathrm{Zn}$ at $50 \mathrm{ppm}$ suppressed the loss in weight than those obtained from $\mathrm{Mg}$ treatment during storage in the two seasons these results agree with those obtained by Mohammed et al. (2009) on snap bean and Atrees and Mohamed (2014) on broccoli. Such results may be due to the beneficial effect of iron and zinc (Lashkeri et al., 2007, Mansour et al.,2012) and magnesium (Kiss, 1989,Mohammed et al., 2009, Ahmed et al (2011)., Darwesh and Atrees, 2011) on vegetative growth and chemical composition of snap bean pods which in turn maintained the metabolic homeostasis after harvest and reduce dehydration of pods. On the contrary, snap bean pods obtained from the control recorded the highest significant weight loss percentage in both seasons.

Concerning the effect of packaging material, snap bean pods packed in polypropylene or stretch reduced the weight loss percentage as compared with unpacked pods during storage in the two seasons, however, polypropylene film

Fayoum J. Agric. Res. \& Dev., Vol. 29, No.1, January, 2015 
EFFECT OF FOLIAR APPLICATION OF MICRONUTRIENTS

was the most effective treatment in reducing the loss in pods weight compared with those packed in stretch film.

The interaction between treatments and packaging materials had significant effect on weight loss percentage. The lowest value was recorded by the interaction between ( $\mathrm{Fe}$ at $100 \mathrm{ppm}+\mathrm{Mn}$ at $100 \mathrm{ppm}$ and $\mathrm{Zn}$ at $50 \mathrm{ppm}$ ) treatment and polypropylene film, while the highest value was recorded by the interaction between control treatment and unpacked pods.

The interaction between pre harvest treatments and storage period was significant in the two seasons. However, the lowest value of weight loss percentage was recorded at the end of storage period from $\mathrm{Fe}$ at $100 \mathrm{ppm}+\mathrm{Mn}$ at $100 \mathrm{ppm}$ and $\mathrm{Zn}$ at $50 \mathrm{ppm}$ treatment.

The interaction between pre harvest treatments, packaging material and storage period was significant in both seasons, however, after 16 days of storage, snap bean pods obtained from plants treated with $\mathrm{Fe}$ at $100 \mathrm{ppm}+\mathrm{Mn}$ at $100 \mathrm{ppm}+\mathrm{Zn}$ at $50 \mathrm{ppm}$ and packed in polypropylene bags showed the least weight loss percentage. These results were true in the two seasons.

Lowest weight loss from snap bean packed in different packaging material is due to the confinement of moisture around the produce by polypropylene or stretch film. This increases the relative humidity and reduces vapor pressure deficit and transpiration. In addition, packaging creates a modified atmosphere with higher concentration of $\mathrm{CO}_{2}$ and reduced $\mathrm{O}_{2}$ around the produce which slows down the metabolic processes and transpiration (Thompson, 1996), which diminished the weight loss during storage (Wang and Qi, 1997). The highest weight loss observed in unpacked fruits throughout the storage period can be attributed to air movement, which tends to sweep away the unstirred layer of air at equilibrium vapor pressure with the tissues adjacent to the surface of the produce, thus increasing the vapor pressure deficits (Wills et al ., 1998).

Fayoum J. Agric. Res. \& Dev., Vol. 29, No.1, January, 2015 
Shehata, S.A. et al.

Table 5: Effect of foliar application of micro elements, magnesium and packaging materials on weight Loss \% of snap bean pods during cold storage in 2012/2013 and 2013/2014 seasons.

\begin{tabular}{|c|c|c|c|c|c|c|c|c|c|c|c|c|c|}
\hline \multirow[t]{3}{*}{ Treat.(T) } & \multirow{3}{*}{$\begin{array}{c}\text { packaging } \\
\text { material }(\mathbf{P})\end{array}$} & \multicolumn{12}{|c|}{ storage period in days $(\mathrm{S})$} \\
\hline & & \multicolumn{6}{|c|}{ 2012/2013 } & \multicolumn{6}{|c|}{$2013 / 2014$} \\
\hline & & $\begin{array}{c}0 \\
\text { time }\end{array}$ & 4 & 8 & 12 & 16 & mean & $\begin{array}{c}0 \\
\text { time }\end{array}$ & 4 & 8 & 12 & 16 & mean \\
\hline \multirow{3}{*}{$\mathbf{F e}+\mathbf{Z n}+\mathbf{M n}$} & polypropylene & 0.00 & 0.10 & 0.13 & 0.18 & 0.32 & 0.15 & 0.00 & 0.14 & 0.19 & 0.23 & 0.43 & 0.20 \\
\hline & stretch & 0.00 & 0.26 & 0.45 & 0.63 & 0.95 & 0.46 & 0.00 & 0.34 & 0.48 & 0.82 & 1.03 & 0.53 \\
\hline & control & 0.00 & 1.93 & 3.11 & 5.72 & 8.25 & 3.80 & 0.00 & 2.11 & 3.32 & 5.16 & 7.62 & 3.63 \\
\hline \multicolumn{2}{|c|}{ mean } & 0.00 & 0.76 & 1.23 & 2.18 & 3.17 & 1.47 & 0.00 & 0.86 & 1.33 & 2.06 & 3.03 & 1.38 \\
\hline \multirow{3}{*}{ Mg } & polypropylene & 0.00 & 0.19 & 0.22 & 0.32 & 0.45 & 0.24 & 0.00 & 0.23 & 0.31 & 0.42 & 0.55 & 0.30 \\
\hline & stretch & 0.00 & 0.30 & 0.52 & 0.74 & 1.23 & 0.56 & 0.00 & 0.34 & 0.59 & 0.81 & 1.36 & 0.62 \\
\hline & \begin{tabular}{|l|} 
control \\
\end{tabular} & 0.00 & 2.14 & 3.62 & 5.91 & 8.62 & 4.06 & 0.00 & 2.17 & 3.51 & 5.84 & 8.72 & 4.05 \\
\hline \multicolumn{2}{|c|}{ mean } & 0.00 & 0.88 & 1.45 & 2.32 & 3.43 & 1.62 & 0.00 & 0.91 & 1.47 & 2.36 & 3.54 & 1.66 \\
\hline \multirow{3}{*}{ Cont. } & polypropylene & 0.00 & 0.22 & 0.30 & 0.42 & 0.57 & 0.30 & 0.00 & 0.24 & 0.33 & 0.48 & 0.64 & 0.34 \\
\hline & stretch & 0.00 & 0.37 & 0.65 & 0.86 & 1.38 & 0.65 & 0.00 & 0.42 & 0.72 & 0.81 & 1.45 & 0.68 \\
\hline & control & 0.00 & 2.41 & 3.83 & 6.26 & 8.94 & 4.29 & 0.00 & 2.58 & 3.91 & 6.41 & 8.90 & 4.36 \\
\hline \multicolumn{2}{|c|}{ mean } & 0.00 & 1.00 & 1.59 & 2.51 & 3.63 & 1.75 & 0.00 & 1.08 & 1.65 & 2.57 & 3.66 & 1.79 \\
\hline \multirow{3}{*}{ Mean } & polypropylene & 0.00 & 0.17 & 0.22 & 0.31 & 0.45 & 0.23 & 0.00 & 0.20 & 0.28 & 0.38 & 0.54 & 0.28 \\
\hline & stretch & 0.00 & 0.31 & 0.54 & 0.74 & 1.19 & 0.56 & 0.00 & 0.37 & 0.60 & 0.81 & 1.28 & 0.61 \\
\hline & control & 0.00 & 2.16 & 3.52 & 5.96 & 8.60 & 4.05 & 0.00 & 2.29 & 3.58 & 5.80 & 8.41 & 4.02 \\
\hline \multicolumn{2}{|c|}{ mean } & 0.00 & 0.84 & 1.37 & 2.28 & 3.34 & 1.57 & 0.00 & 0.91 & 1.43 & 2.25 & 3.33 & 1.56 \\
\hline \multirow{7}{*}{$\begin{array}{l}\text { LSD at } 0.05 \\
\text { level }\end{array}$} & $\mathbf{T}$ & 0.10 & & & & & & 0.09 & & & & & \\
\hline & $\mathbf{P}$ & 0.11 & & & & & & 0.11 & & & & & \\
\hline & $\mathbf{S}$ & 0.12 & & & & & & 0.11 & & & & & \\
\hline & $\mathbf{T} * \mathbf{P}$ & 0.12 & & & & & & 0.12 & & & & & \\
\hline & $\mathbf{T} * \mathbf{S}$ & 0.14 & & & & & & 0.17 & & & & & \\
\hline & $\mathbf{P} * \mathbf{S}$ & 0.16 & & & & & & 0.17 & & & & & \\
\hline & $\mathbf{T} * \mathbf{P} * \mathbf{S}$ & 0.17 & & & & & & 0.20 & & & & & \\
\hline
\end{tabular}

\section{General appearance (GA)}

Data in Table (6) showed that there was significant reduction in GA with the prolongation of storage period in both seasons. Similar results were reported by Mohammed $\boldsymbol{e t}$ al. (2009). The decreases in GA during storage of snap bean pods might be due to shriveling with color change and decay (El- Mogy, 2001).

All treatments had higher score of GA when compared with the control. However, snap bean pods obtained from plants treated with Fe at $100 \mathrm{ppm}+$ $\mathrm{Mn}$ at $100 \mathrm{ppm}$ and $\mathrm{Zn}$ at $50 \mathrm{ppm}$ or $\mathrm{Mg}$ at $0.5 \%$ had the best GA with significant differences between them. The worst GA recorded for the untreated control. These results were true in the two seasons and agree with those obtained by Atrees and Mohamed (2014) on broccoli and Mohammed et al. (2009) on snap beans. Such results may be due to the useful role of iron, Mn and magnesium in reducing weight loss percentage and maintaining green color during storage (Atrees and Mohamed, 2014).

Fayoum J. Agric. Res. \& Dev., Vol. 29, No.1, January, 2015 
EFFECT OF FOLIAR APPLICATION OF MICRONUTRIENTS

Table 6: Effect of foliar spraying of micro elements, magnesium and packaging materials on general appearance ( score) of snap bean pods during cold storage in 2012/2013 and 2013/2014 seasons.

\begin{tabular}{|c|c|c|c|c|c|c|c|c|c|c|c|c|c|}
\hline \multirow{3}{*}{$\begin{array}{c}\text { Treat. } \\
\text { (T) }\end{array}$} & \multirow{3}{*}{$\begin{array}{c}\text { packaging } \\
\text { material }(\mathbf{P})\end{array}$} & \multicolumn{12}{|c|}{ storage period in days $(\mathrm{S})$} \\
\hline & & \multicolumn{6}{|c|}{$2012 / 2013$} & \multicolumn{6}{|c|}{$2013 / 2014$} \\
\hline & & $\begin{array}{c}0 \\
\text { time }\end{array}$ & 4 & 8 & 12 & 16 & mean & $\begin{array}{c}0 \\
\text { time }\end{array}$ & 4 & 8 & 12 & 16 & mean \\
\hline \multirow{3}{*}{$\begin{array}{l}\mathrm{Fe}+ \\
\mathrm{Zn}+ \\
\mathrm{Mn}\end{array}$} & polypropylene & 9.00 & 9.00 & 9.00 & 9.00 & 7.67 & 8.73 & 9.00 & 9.00 & 9.00 & 8.33 & 7.00 & 8.47 \\
\hline & stretch & 9.00 & 9.00 & 8.33 & 7.67 & 6.33 & 8.07 & 9.00 & 9.00 & 8.33 & 7.00 & 6.33 & 7.93 \\
\hline & control & 9.00 & 9.00 & 7.67 & 6.33 & 5.00 & 7.40 & 9.00 & 9.00 & 7.00 & 6.33 & 5.00 & 7.27 \\
\hline \multicolumn{2}{|r|}{ mean } & 9.00 & 9.00 & 8.33 & 7.67 & 6.33 & 8.07 & 9.00 & 9.00 & 8.11 & 7.22 & 6.11 & 7.89 \\
\hline \multirow{3}{*}{ Mg } & polypropylene & 9.00 & 9.00 & 8.33 & 7.67 & 6.33 & 8.07 & 9.00 & 9.00 & 9.00 & 7.67 & 6.33 & 8.20 \\
\hline & stretch & 9.00 & 9.00 & 7.67 & 7.00 & 5.67 & 7.67 & 9.00 & 9.00 & 8.33 & 7.00 & 5.00 & 7.67 \\
\hline & \begin{tabular}{|l|} 
control \\
\end{tabular} & 9.00 & 9.00 & 7.00 & 5.67 & 4.33 & 7.00 & 9.00 & 9.00 & 7.67 & 5.00 & 4.33 & 7.00 \\
\hline \multicolumn{2}{|r|}{ mean } & 9.00 & 9.00 & 7.67 & 6.78 & 5.44 & 7.58 & 9.00 & 9.00 & 8.33 & 6.56 & 5.22 & 7.62 \\
\hline \multirow{3}{*}{$\begin{array}{c}\text { Cont } \\
\text {. }\end{array}$} & polypropylene & 9.00 & 9.00 & 7.67 & 6.33 & 4.33 & 7.27 & 9.00 & 9.00 & 7.67 & 6.33 & 5.00 & 7.40 \\
\hline & stretch & 9.00 & 9.00 & 7.00 & 6.33 & 4.80 & 7.23 & 9.00 & 9.00 & 7.00 & 6.33 & 5.67 & 7.40 \\
\hline & \begin{tabular}{|l|} 
control \\
\end{tabular} & 9.00 & 8.33 & 6.33 & 4.33 & 3.00 & 6.20 & 9.00 & 9.00 & 5.00 & 3.67 & 3.00 & 5.93 \\
\hline \multicolumn{2}{|c|}{ mean } & 9.00 & 8.78 & 7.00 & 5.66 & 4.04 & 6.90 & 9.00 & 9.00 & 6.56 & 5.44 & 4.56 & 6.91 \\
\hline \multirow{3}{*}{ mean } & polypropylene & 9.00 & 9.00 & 8.33 & 7.67 & 6.11 & 8.02 & 9.00 & 9.00 & 8.56 & 7.44 & 6.11 & 8.02 \\
\hline & stretch & 9.00 & 9.00 & 7.67 & 7.00 & 5.60 & 7.65 & 9.00 & 9.00 & 7.89 & 6.78 & 5.67 & 7.67 \\
\hline & control & 9.00 & 8.78 & 7.00 & 5.44 & 4.11 & 6.87 & 9.00 & 9.00 & 6.56 & 5.00 & 4.11 & 6.73 \\
\hline \multicolumn{2}{|r|}{ mean } & 9.00 & 8.93 & 7.67 & 6.70 & 5.27 & 7.51 & 9.00 & 9.00 & 7.67 & 6.41 & 5.30 & 7.47 \\
\hline \multirow{7}{*}{\begin{tabular}{|l|} 
LSD \\
at \\
o.05 \\
level
\end{tabular}} & $\mathbf{T}$ & 0.39 & & & & & & 0.31 & & & & & \\
\hline & $\mathbf{P}$ & 0.35 & & & & & & 0.32 & & & & & \\
\hline & $\mathbf{S}$ & 0.40 & & & & & & 0.34 & & & & & \\
\hline & $\mathbf{T} * \mathbf{P}$ & 0.42 & & & & & & 0.36 & & & & & \\
\hline & $\mathbf{T} * \mathbf{S}$ & NS & & & & & & 0.40 & & & & & \\
\hline & $\mathbf{P} * \mathbf{S}$ & NS & & & & & & 0.42 & & & & & \\
\hline & $\mathbf{T} * \mathbf{P} * \mathbf{S}$ & 0.49 & & & & & & 0.46 & & & & & \\
\hline
\end{tabular}

Significant differences in appearance were found between the two packaging materials and control on snap bean pods during storage. Snap bean stored in polypropylene film was perceived to have the highest intensities of freshness, greenness and crispness, while unpacked control was perceived to have low intensities of these attributes. These results were true in the two seasons and agree with those obtained by Jia et al. (2009) and Mohamed, (2013) on broccoli.

The interaction between treatments and packaging materials was significant in the two seasons, however, the highest score of general appearance was in pods obtained from plants treated with Fe at $100 \mathrm{ppm}+\mathrm{Mn}$ at $100 \mathrm{ppm}$ and $\mathrm{Zn}$ at $50 \mathrm{ppm}$ and packed in polypropylene film. While the interaction between pre harvest treatment and storage period was significant only in the second season.

The interaction among the pre harvest treatments, packaging materials and storage period revealed that snap bean pods obtained from plants treated with $\mathrm{Fe}$ at $100 \mathrm{ppm}+\mathrm{Mn}$ at $100 \mathrm{ppm}$ and $\mathrm{Zn}$ at $50 \mathrm{ppm}$ and packaged in poly propylene film did not exhibit any changes in their appearance till $12^{\text {th }}$ days

Fayoum J. Agric. Res. \& Dev., Vol. 29, No.1, January, 2015 
Shehata, S.A. et al.

and gave good appearance after 16 days of storage at $6{ }^{\circ} \mathrm{C}$, while pods which obtained from plants treated with $\mathrm{Mg}$ at $0.5 \%$ and packed in polypropylene film rated good appearance after 12 days of storage. On the other hand untreated and un packed treatment rated the poorest appearance at the end of storage at $6^{\circ} \mathrm{C}$. The previous results were true in the two seasons.

\section{Total chlorophyll}

Data in Table 7 showed that total chlorophyll content in snap bean pods was decreased gradually during storage. This decrement could be attributed to gradual increase in of destruction by chlorophyll degrading peroxidase (POD) activity which is transformation chloroplast to chromoplasts (Charles and Rjb 1991). These result agree with those obtained from Mohammed et al.,( 2009) and Kinyuru et al., (2011).

Concerning the effect of foliar spray with micro nutrients, data revealed that snap bean pods obtained from plants treated with Fe at 100ppm $+\mathrm{Mn}$ at $100 \mathrm{ppm}$ and $\mathrm{Zn}$ at $50 \mathrm{ppm}$ or $\mathrm{Mg}$ at $0.5 \%$ had the highest total chlorophyll content during storage with significant differences between them. However, the lowest ones were obtained from untreated (control). These results were true in the two seasons and agree with those obtained by Mohammed et al. (2009).

For the effect of packaging materials, data showed that there were significant differences between packaging materials and the control. The highest total chlorophyll content was obtained from pods packaged in polypropylene film followed by those packed in stretch film with significant differences between them. However, the lowest ones was obtained from unpacked pods during storage. These results were true in the two seasons and agree with those obtained Kinyru $\boldsymbol{e t}$ al., (2011) who found that changes in snap bean pod color at the end of storage preceded more slowly in fruits packed in polypropylene bags, however, the colors of unpacked fruits changed rapidly.

The interaction between pre harvest treatment and packaging materials was significant, however, snap bean pods obtained from plants treated with Fe at 100 $\mathrm{ppm}+\mathrm{Mn}$ at $100 \mathrm{ppm}$ and $\mathrm{Zn}$ at $50 \mathrm{ppm}$ and then packed in polypropylene film had the highest value of chlorophyll content. The interaction between pre harvest treatments and storage period was significant.

The interaction among pre harvest treatments, packaging materials and storage period was significant. However after 16 days of storage, snap bean pods obtained from plants treated with Fe at 100 ppm +Mn at $100 \mathrm{ppm}$ and $\mathrm{Zn}$ at $50 \mathrm{ppm}$ and packed in polypropylene film had the highest value of chlorophyll content, while the lowest one was found in those obtained from plants sprayed with distilled water and unpacked at the same period of storage.

Fayoum J. Agric. Res. \& Dev., Vol. 29, No.1, January, 2015 
EFFECT OF FOLIAR APPLICATION OF MICRONUTRIENTS 133

Table (7): Effect of foliar spraying of micro elements , magnesium and packaging materials on total chlorophyll content $(\mathrm{mg} / \mathbf{1 0 0 g} \mathrm{FW})$ of snap bean pods during cold storage in 2012/2013 and 2013/2014 seasons

\begin{tabular}{|c|c|c|c|c|c|c|c|c|c|c|c|c|c|}
\hline \multirow{3}{*}{$\begin{array}{c}\text { Treat. } \\
(\mathrm{T})\end{array}$} & \multirow{3}{*}{$\begin{array}{c}\text { packaging } \\
\text { material(P) }\end{array}$} & \multicolumn{12}{|c|}{ storage period in days $(\mathrm{S})$} \\
\hline & & \multicolumn{6}{|c|}{$2012 / 2013$} & \multicolumn{6}{|c|}{$2013 / 2014$} \\
\hline & & 0 time & 4 & 8 & 12 & 16 & mean & O time & 4 & 8 & 12 & 16 & mean \\
\hline \multirow{4}{*}{$\begin{array}{l}\mathrm{Fe}+ \\
\mathrm{Zn}+ \\
\mathrm{Mn}\end{array}$} & polypropylene & 110.30 & 108.30 & 105.40 & 101.70 & 98.30 & 104.80 & 98.40 & \multicolumn{3}{|c|}{96.5093 .4090 .70} & 87.10 & 93.22 \\
\hline & stretch & 110.30 & 104.30 & 100.30 & 98.20 & 95.30 & 101.68 & 98.40 & \multicolumn{3}{|c|}{\begin{tabular}{|l|l|l|}
93.50 & 90.20 & 88.10 \\
\end{tabular}} & 84.30 & 90.90 \\
\hline & control & 110.30 & 102.80 & 95.80 & 90.60 & 84.30 & 96.76 & 98.40 & \multicolumn{3}{|c|}{\begin{tabular}{|l|l|l|l|}
90.30 & 87.20 & 83.40 \\
\end{tabular}} & 80.70 & 88.00 \\
\hline & mean & 110.30 & 105.13 & 100.50 & 96.83 & 92.63 & 101.08 & 98.40 & \multicolumn{3}{|c|}{ 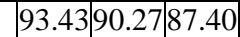 } & 84.03 & 90.71 \\
\hline \multirow{3}{*}{ Mg } & polypropylene & 107.70 & 103.40 & 101.50 & 97.20 & 93.70 & 100.70 & 96.20 & \multicolumn{3}{|c|}{94.3092 .0088 .80} & 85.70 & 91.40 \\
\hline & stretch & 107.70 & 98.30 & 95.30 & 92.40 & 88.20 & 96.38 & 96.20 & \multicolumn{3}{|c|}{91.7088 .3085 .40} & 83.20 & 88.96 \\
\hline & control & 107.70 & 97.70 & 91.20 & 86.30 & 81.10 & 92.80 & 96.20 & \multicolumn{3}{|c|}{\begin{tabular}{|l|l|l|}
91.30 & 85.10 & 80.20 \\
\end{tabular}} & 77.40 & 86.04 \\
\hline & mean & 107.70 & 99.80 & 96.00 & 91.97 & 87.67 & 96.63 & 96.20 & \multicolumn{3}{|c|}{\begin{tabular}{|l|l|l|}
92.43 & 88.47 & 84.80 \\
\end{tabular}} & 82.10 & 88.80 \\
\hline \multirow{4}{*}{ Cont. } & polypropylene & 102.40 & 96.10 & 89.30 & 83.70 & 78.40 & 89.98 & 92.50 & \multicolumn{3}{|c|}{\begin{tabular}{|l|l|l|}
88.3084 .10 & 81.20 \\
\end{tabular}} & 78.40 & 84.90 \\
\hline & stretch & 102.40 & 94.20 & 85.10 & 80.30 & 73.10 & 87.02 & 92.50 & \multicolumn{3}{|c|}{88.2083 .4078 .50} & 76.20 & 83.76 \\
\hline & control & 102.40 & 92.40 & 82.40 & 76.40 & 70.30 & 84.78 & 92.50 & \multicolumn{3}{|c|}{85.1081 .2076 .40} & 71.50 & 81.34 \\
\hline & mean & 102.40 & 94.23 & 85.60 & 80.13 & 73.93 & 87.26 & 92.50 & \multicolumn{3}{|c|}{87.2082 .9078 .70} & 75.37 & 83.33 \\
\hline \multirow{4}{*}{ mean } & polypropylene & 106.80 & 102.60 & 98.73 & 94.20 & 90.13 & 98.49 & 95.70 & \multicolumn{3}{|c|}{\begin{tabular}{|l|l|l|}
93.03 & 89.83 & 86.90 \\
\end{tabular}} & 83.73 & 89.84 \\
\hline & stretch & 106.80 & 98.93 & 93.57 & 90.30 & 85.53 & 95.03 & 95.70 & \multicolumn{3}{|c|}{\begin{tabular}{|l|l|l|}
91.13 & 87.30 & 84.00 \\
\end{tabular}} & 81.23 & 87.87 \\
\hline & control & 106.80 & 97.63 & 89.80 & 84.43 & 78.57 & 91.45 & 95.70 & \multicolumn{3}{|c|}{$88.9084 .50 \mid 80.00$} & 76.53 & 85.13 \\
\hline & mean & 106.80 & 99.72 & 94.03 & 89.64 & 84.74 & 94.99 & 95.70 & \multicolumn{3}{|c|}{\begin{tabular}{|l|l|l|}
91.02 & 87.21 & 83.63 \\
\end{tabular}} & 80.50 & 87.61 \\
\hline \multirow{7}{*}{\begin{tabular}{|l} 
LSD \\
at \\
o.05 \\
level
\end{tabular}} & $\mathbf{T}$ & 1.74 & & & & & & 1.31 & & & & & \\
\hline & $\mathbf{P}$ & 1.87 & & & & & & 1.37 & & & & & \\
\hline & $\mathbf{S}$ & 1.91 & & & & & & 1.42 & & & & & \\
\hline & $\mathbf{T} * \mathbf{P}$ & 2.11 & & & & & & 1.65 & & & & & \\
\hline & $\mathbf{T} * \mathbf{S}$ & 2.13 & & & & & & 1.82 & & & & & \\
\hline & $\mathbf{P} * \mathbf{S}$ & 2.50 & & & & & & 1.98 & & & & & \\
\hline & $\mathbf{T} * \mathbf{P} * \mathbf{S}$ & 2.55 & & & & & & 2.06 & & & & & \\
\hline
\end{tabular}

Ascorbic acid:

Data in Table 8 showed that ascorbic acid content of snap bean pods was decreased by the prolongation of storage period. These results are true in the two seasons and agree with those obtained by Kinyru et al., (2011) this reduction might be due to the higher rate of sugar loss through respiration than water loss through transpiration (Wills et al., 1998).

Concerning the effect of foliar spray with micro nutrients, data revealed that there were significant differences between treatments in their ascorbic acid content during storage, however, snap bean pods obtained from plants treated with $\mathrm{Fe}$ at $100 \mathrm{ppm}+\mathrm{Mn}$ at $100 \mathrm{ppm}$ and $\mathrm{Zn}$ at $50 \mathrm{ppm}$ or $\mathrm{Mg}$ at $0.5 \%$ were higher in fruit ascorbic acid with significant differences between them compared with untreated (control). These results were true in the two seasons.

Regarding the effect of packaging materials, data in the same Table 8 indicated that snap bean pods packed in polypropylene or stretch film were significantly higher in ascorbic acid with no significant differences between them than unpacked pods during storage. These results were true in the two seasons and agree with those of Kinyuru et al.,(2012) who found, in snap bean, that pods packed in different packing materials prevent ascorbic acid content degradation caused by low $\mathrm{O}_{2}$ concentration in this way, ascorbic acid changes in plastic material treated were suppressed.

Fayoum J. Agric. Res. \& Dev., Vol. 29, No.1, January, 2015 
Shehata, S.A. et al.

The interaction between pre harvest treatments and packaging materials was significant, however, snap bean pods obtained from plants treated with $\mathrm{Fe}$ at 100 ppm $+\mathrm{Mn}$ at $100 \mathrm{ppm}$ and $\mathrm{Zn}$ at $50 \mathrm{ppm}$ and then packed in polypropylene film or stretch film had the highest values of ascorbic acid content, while, the lowest one was obtained from pre harvest control and unpacked pods.

The interaction between pre harvest treatments and storage period was non significant in the two seasons.

For the interaction among pre harvest treatments, packaging materials and storage period, data in Table 7 revealed that snap bean pods obtained from plant treated with $\mathrm{Fe}$ at $100 \mathrm{ppm}+\mathrm{Mn}$ at $100 \mathrm{ppm}$ and $\mathrm{Zn}$ at $50 \mathrm{ppm}$ and packed in polypropylene film or stretch were the best in maintaining ascorbic acid content at the end of storage period (16 days of storage).

Table 8: Effect of foliar spraying of micro elements , magnesium and packaging materials on ascorbic acid content $(\mathbf{m g} / \mathbf{1 0 0 g}$ FW)of snap bean pods during cold storage in 2012/2013 and 2013/2014 seasons.

\begin{tabular}{|c|c|c|c|c|c|c|c|c|c|c|c|c|c|}
\hline \multirow{3}{*}{$\begin{array}{c}\text { Treat. } \\
\text { (T) }\end{array}$} & \multirow{3}{*}{$\begin{array}{l}\text { packaging } \\
\text { material(P) }\end{array}$} & \multicolumn{12}{|c|}{ storage period in days $(\mathrm{S})$} \\
\hline & & \multicolumn{6}{|c|}{$2012 / 2013$} & \multicolumn{6}{|c|}{ 2013/2014 } \\
\hline & & 0 time & 4 & 8 & 12 & 16 & mean & 0 time & 4 & 8 & 12 & 16 & mean \\
\hline \multirow{3}{*}{$\begin{array}{l}\mathrm{Fe}+ \\
\mathrm{Zn}+ \\
\mathbf{M n}\end{array}$} & polypropylene & 23.40 & 22.60 & 22.10 & 21.50 & 19.31 & 21.78 & 20.50 & 19.72 & 18.14 & 18.82 & 17.23 & 18.88 \\
\hline & stretch & 23.40 & 22.49 & 22.00 & 21.32 & 19.11 & 21.66 & 20.50 & 19.61 & 18.24 & 18.63 & 17.10 & 18.82 \\
\hline & control & 23.40 & 22.20 & 21.86 & 21.04 & 17.51 & 21.20 & 20.50 & 19.02 & 17.64 & 16.13 & 15.92 & 17.84 \\
\hline \multicolumn{2}{|r|}{ mean } & 23.40 & 22.43 & 21.99 & 21.29 & 18.64 & 21.55 & 20.50 & 19.45 & 18.01 & 17.86 & 16.75 & 18.51 \\
\hline \multirow{3}{*}{ Mg } & polypropylene & 22.30 & 21.50 & 20.94 & 20.13 & 17.24 & 20.42 & 19.10 & 18.03 & 17.00 & 16.14 & 15.60 & 17.17 \\
\hline & stretch & 22.30 & 21.35 & 20.82 & 20.00 & 17.09 & 20.31 & 19.10 & 17.92 & 16.91 & 15.90 & 15.10 & 16.99 \\
\hline & control & 22.30 & 21.06 & 20.12 & 19.07 & 15.13 & 19.54 & 19.10 & 16.24 & 14.92 & 13.51 & 11.64 & 15.08 \\
\hline \multicolumn{2}{|r|}{ mean } & 22.30 & 21.30 & 20.63 & 19.73 & 16.49 & 20.09 & 19.10 & 17.40 & 16.28 & 15.18 & 14.11 & 16.41 \\
\hline \multirow{3}{*}{ Cont. } & polypropylene & 19.10 & 18.06 & 17.12 & 16.10 & 13.36 & 16.75 & 17.70 & 16.60 & 14.90 & 13.52 & 12.31 & 15.01 \\
\hline & stretch & 19.10 & 17.93 & 16.92 & 15.83 & 13.20 & 16.60 & 17.70 & 16.50 & 14.83 & 13.23 & 12.17 & 14.89 \\
\hline & control & 19.10 & 16.23 & 14.82 & 13.50 & 1.13 & 12.96 & 17.70 & 16.04 & 14.12 & 12.93 & 11.02 & 14.36 \\
\hline \multicolumn{2}{|r|}{ mean } & 19.10 & 17.41 & 16.29 & 15.14 & 9.23 & 15.43 & 17.70 & 16.38 & 14.62 & 13.23 & 11.83 & 14.75 \\
\hline \multirow{3}{*}{ mean } & polypropylene & 21.60 & 20.72 & 20.05 & 19.24 & 16.64 & 19.65 & 19.10 & 18.12 & 16.68 & 16.16 & 15.05 & 17.02 \\
\hline & stretch & 21.60 & 20.59 & 19.91 & 19.05 & 16.47 & 19.52 & 19.10 & 18.01 & 16.66 & 15.92 & 14.79 & 16.90 \\
\hline & control & 21.60 & 19.83 & 18.93 & 17.87 & 11.26 & 17.90 & 19.10 & 17.10 & 15.56 & 14.19 & 12.86 & 15.76 \\
\hline \multicolumn{2}{|r|}{ mean } & 22.43 & 21.37 & 20.75 & 19.91 & 16.64 & 20.22 & 19.57 & 18.20 & 16.86 & 16.16 & 15.03 & 17.16 \\
\hline \multirow{7}{*}{\begin{tabular}{|c|} 
LSD at \\
0.05 \\
level
\end{tabular}} & $\mathbf{T}$ & 0.24 & & & & & & 0.23 & & & & & \\
\hline & $\mathbf{P}$ & 0.24 & & & & & & 0.24 & & & & & \\
\hline & $\mathbf{S}$ & 0.26 & & & & & & 0.28 & & & & & \\
\hline & $\mathbf{T} * \mathbf{P}$ & 0.28 & & & & & & 0.29 & & & & & \\
\hline & $\mathbf{T} * \mathbf{S}$ & NS & & & & & & NS & & & & & \\
\hline & $\mathbf{P} * \mathbf{S}$ & NS & & & & & & NS & & & & & \\
\hline & $\mathbf{T} * \mathbf{P} * \mathbf{S}$ & 0.92 & & & & & & 0.36 & & & & & \\
\hline
\end{tabular}

\section{CONCLUSION}

From the previous results it could be concluded that spraying snap bean plants with $\mathrm{Fe}$ at $100 \mathrm{ppm}+\mathrm{Mn}$ at $100 \mathrm{ppm}$ and $\mathrm{Zn}$ at $50 \mathrm{ppm}$ improved vegetative growth, yield and its components and pod quality. Snap bean pods obtained from this treatment and packed in polypropylene film maintained pod quality during storage for 16 days at $6{ }^{\circ} \mathrm{C}$ and $95 \%$ relative humidity.

Concerning the effect of packaging material, polypropylene film was the most effective treatment in reducing the loss in pods weight, gave the best

Fayoum J. Agric. Res. \& Dev., Vol. 29, No.1, January, 2015 
appearence, maintained the highest total chlorophyll content and ascorbic acid compared with unpacked pods during storage.

\section{REFERENCES}

Abd- El-Lateef, E.M., Ashour, N.I. and A.A. Farrage .(1998). Effect of foliar spray with urea and some micro nutrients on Mung bean (Vigna radiate( L) Wilczek) growth, yield and seed chemical composition. Bulletin of the National Research Center, Cairo.23 (2):219-232.

Ahmed, M.E., A.A.Elzaawely and M.B.El-Sawy (2011). Effect of the foliar spraying with molybdenum and magnesium on vegetative growth and crud yields in cauliflower (Brassica Oleracea var botrytis L. ).World J. Agric. Sci. 7 (2) : 149-156.

Allison.M.F., J.H.Fower and E.J.Allen (2001). Factors affecting the magnesium nutrition of potatoes (solanum tuberosum L.). J.AGgric.Sci. Cambridge., 137:397-409.

A.O.A.C. (1990). Quality of Official Analytical Chemist, Washington DC. USA.

Atrees,A.S.H. and O.O. Mohamed (2014). Impact of foliar spraying with iron and magnesium on growth, yield, chemical constituents and storability of broccoli. Annals of Agric. Sci., Moshtohor, 52 (2): 261 - 272.

Brittenhan, G.M.(1994). New advances in iron metabolism, iron deficiency and Iron overload. Current opinion in hematology, 1:549-556.

Charles,F.F. and R.E. Rjb.(1991). Temperature of broccoli at time of packaging influnces package. HortScince $26: 1301-1303$.

Darwesh, F.M.A. and A.S.H.Atrees (2011). Effect of spraying with potassium and magnesium on yield, quality and storability of snow bea (Pisum sativum var macrocarpon ). J.Appli Sci. ,26 (12) : 312 - 327.

Delvin, R.M. and F.H.Witham. (1986). Plant Physiology . 4 th ed. CBS publishers and distributors 485. Jain Bhawan. Shadhora, Delhi, 110032. (India).

El- Bassiony, A.M., Z.F.Fawzy, M.M.H.Abd El-Baky and A.R.Mahmoud(2010). Response of snap bean plants to mineral fertilizers and humic acid application. Res. J. Agric. Biol. Sci 6 (2): $169-175$.

El-Mogy, M.M. (2001) . Effect of some pre and postharvest treatments on storagability of some snap bean cultivars. M.Sc.Thesis, Fac. Agric., Cairo Univ., Egypt.

El- Tantawy, E.M. and D.A.S.Nawar (2013). Nodulation, growth, photosynthetic pigments and yield of broad bean plants ( Visia faba L.) as affected by nitrogene source, rizobium inoculation and iron foliar application . J. Appl. Sci. Res.,9 (1):974-987.

El- Tantawy ,E.M. and M.I.Mahmoud (2013). Effect of nitrogene source , rhizobium inoculation and foliar spray with Ironn on plant growth, pod

Fayoum J. Agric. Res. \& Dev., Vol. 29, No.1, January, 2015 
characters and yield of broad bean plants (vicia faba L.). HortScince J. Suez Canal Univ., 1:203-210.

El- Tohamy ,W.A. and N.H.M.Greadly. (2007). Physiological responses, growth, yield and quality of snap bean in response to foliar application of yeast, vitamin $\mathrm{E}$ and zinc under sandy soil conditions. Austerlian J. of Basic and Appli.Sci. , 1(3) : $294-29$.

El- Sayed, H.A. (1991 a). Effect of Fe,Mn,Zn and B on the growth and yield of snap bean plants. J.Agric. Sc., Mansoura Univ.,16 (2) : 402-406.

El- Sayed, H.A. (1991 b).Growth and yield of potato as affected by CCC , GA and vitamin C. J.Agric.Sci., Mansoura Univ. 16 (3) : 648- 652.

Havlin, J.L., J.D.Beatan, S.L.Tisdale and W.L.Nelson(1999). Soil Fertility and Fertilizers. An introduction to nutrient management 6 th ED. Prentice Hall, New Jersey. Res., J. of Agric. Biol. Sci.,4(6): 717-724.

Ibrahim,H.A., U.A.El- Behairy, M.El-Desuki, M.O.Bakry and A.F.AbouHadid. (2010). Response of green bean to fertilization with potassium and magnesium. Res. J.of Agric. And Biol. Sci., 6(6): 834 -839.

Jia,C., C.Xu, J.Wei, J.Yuan, G.Yuan, B.Wang and Q.Wang (2009). Effect of modified atmosphere packaging on visual quality and glucosinolates of broccoli florets. Food Chemistry 114: 28 - 37.

Kabata-Pendias, A. and H.Pendias, (1992). Trace Elements in Soil and Plants 2 nd ed. CRC Press, Boca Raton An Arbor,London.365 pp.

Karaman, M.R., A.R.Brohi,A.Inal and S.Taban. (1999). Effect of iron and zinc applications on growth and mineral nutrient concentrations of beans (Phaseolus vulgaris L.) grown in artificial siltation soils. Turkish J.Agric. and Forestry, 23 (2): $341-348$.

Kinyuru, J.N.,P.K. Kahenya, M.Muchui and H.Mungai.(2011). Influence of postharvest handling on the quality of snab bean (Phaseolus vulgaris L.). J.Agric. Food Tech.,1(5) 43-46.

Kirkby,E.A. and V.Rombeld, (2004). Micronutrients in plant physiology : functions, uptake and mobility. Proceeding No. 534, International fertilizer socity.

Kiss,S.A., (1989). Effect of magnesium on the onion uptake of plant . Acta. Agronom.Hung., 38: 23-29.

Lashkeri, C.O., A.N.Makwana and M.A.Meman,(2007). Effect of Zinc and Iron on growth and yield of cauliflower (Brassica oleracea var. Botrytis linn) CV.Snowball- 16 - Asian J.Hort.,2(2):277-279.

Mansour, N.T.S., D.M.Mostafa and W.M.Abd El-Hakim (2012). Effect of potassium dissolving bacteria abd foliar application with some micro elements on growth, yield and quality of pea plant under sandy soil conditions. Zagazig .J. Agric.Res. ,39 (5): 839-848.

Fayoum J. Agric. Res. \& Dev., Vol. 29, No.1, January, 2015 
EFFECT OF FOLIAR APPLICATION OF MICRONUTRIENTS .137

Marchner, H., (1995). Mineral Nutration of Higher plants .2 nd ED.Academic,Press,London.

Mohamed, F.I and S.H. Kandeel, (1994). Effect of Iron ,Manganese foliar application on growth, green yield, N.P. and protein content of snap bean. Egypt. J. Appl. Sci. 9 (1) : 638-646.

Mohamed, M.E. (2013).Effect of modified atmosohere storage on postharvest quality of some Non- traditional vegetable crops. Ph.D. Thesis, Fac. Agric. Ain Shams Univ.,Cairo Egypt,105p.

Mohammed, O.O., H.M.Arisha, A.Bardisi and R. El-Bassiouny,(2009). Effect of foliar spray with $\mathrm{Ca}, \mathrm{Mg}$ and vitamin $\mathrm{B} 1$ on the productivity and storability of snap bean grown in sandy soil. Zagazig J. Agric. Res., 36 (1): 41-62.

Nadergoli, M.S.,M.Yarnia and F.R.Khoei. (2011). Effect of zinc and manganese and their application on yield and yield components of common bean (Phaseolus vulgaris L.cv.Khomein). middele- east j. Scintific Res. 8(5):859- 865.

Olivira, I.P.de., C.J.Asher, D.G.Edwards and R.S.M.dos.Santos.(2000). Magnesium sulphate and the development of the common bean cultivated in ultisol of Northeast Australia.Scintia Agricola, 57 (1): $153-157$.

Soliman, K.A. (2004). The quality of sweet fennel as influenced by foliar spray with $\mathrm{Mg}+2$, packing and period of storage under cold conditions. J.Adv. Agric. Res. Fac. Agric, Saba Bashaa, Alex,9(2):313-331.

Snedwcor,G.W. and W.G.Cochran. (1980). Statistical methods, 7 th ed. Iowa state univ. press. Ames . Iowa. USA.

Srivasta, D.C. and U.C.Gupta.(1996). Trace elements in crop production, scinc pub. Inc.Lebanon. NH03766 USA.

Swiereczewska, M. and H. Sztuder. (2001). Response of cultivated plants to foliar magnesium fertilization. Soils and Fertilizers, 65 (8):1610.

Thompson, A.K. (1996). Post harvest technology of fruits and vegetables. Oxford: Blackwell Science, $410 \mathrm{pp}$

Teixeira, I.R., A.B.Boren and G.A.A.Araujo (2004). Manganese and zinc leaf application on common bean grown on a cerrado. Soil. Sci. Agric.(Braz.), 61:77-81.

Wang,C.Y. and I.Qi. (1997). Modified atmosphere package alleviates chilling in cucumbers. Postharvest biology and technology, 10: 195-200.

Wang - Hong, C.D. and L.Bao. (1999). A comparative study on the anatomy of common beans subjected to $\mathrm{Mg}$ deficiency and normal $\mathrm{Mg}$ supply. Scientia agricultura Sinica, 32(4) : 63- 67.

Wills,R.B.H.,W.BMcGlasson， D.Graham,T.H.Lee and E.G.Hall.(1989). Post harvest an introduction to the physiology and handling of fruit and vegetables, 3 rd edit . New Yourk. Van Nostrand Reinhol.

Fayoum J. Agric. Res. \& Dev., Vol. 29, No.1, January, 2015 
Shehata, S.A. et al.

Wills,R.McGlasson, b.Graham,d.and Joyee, D.(1998). Post harvest : An Introduction to the physiology and Handling of fruit, vegetables and ornamentals. Wallingford: CAB international, 262pp.

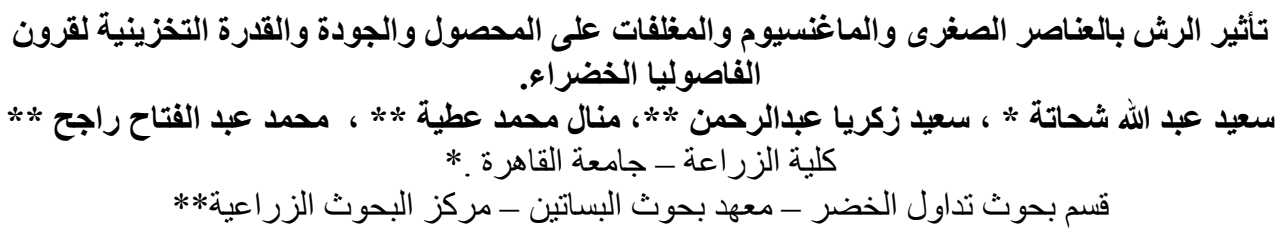

Fayoum J. Agric. Res. \& Dev., Vol. 29, No.1, January, 2015 